\title{
短時間単位降雨 (15分単位)の水文流出逿程について
}

\section{Runoff Process with Short Time Interval Hydrological Data}

\author{
小澤藤弥 清水 洋 福田 $\stackrel{*}{*}$ 小澤真弘 永田謙二
} BY Fujiya OZAWA, Hiroshi SHIMIZU, Minoru FUKUDA, Masahiro OZAWA, Kenji NAGATA

\begin{abstract}
The flood prediction is difficult because runoff process is distinctly non-linear, especially with short time interval hydorological data. Based on the runoff analysis of the 15-minute hydrological data by the filter separation AR method, this paper explains the hydrological runoff process and shows the relationship between pre-flood discharge rate and groundwater infiltration capacity, as well as the relationship between area ratio contributed to runoff and catchment area storage volume.
\end{abstract}

Keywords : runoff process, infiltration, storage volume

\section{1. はじめに}

洪水流量の解析では眝留関数法が9割以上を占め、日本における代表的な洪水解析手法となっている。洪 水調節、水道用水および発電を目的とする三保ダム (流域面積 $158.5 \mathrm{~km}^{2}$ ) は洪水時にゲート操作を必要とする ダムであるが、このようなダムでは、洪水ピーク流量を予測して洪水を安全に流下させるためのゲート操作 あ重要であるが、洪水莪減期の流量予測に基づいて無効放流をできるだけ少なくするような洪水末期のゲー 卜閉塞操作む、水資源の有効利用という立場から非常に重要である。

本論文は、流出過程の非線形性がより強く現れると考えられる短時間単位の水文データ(15分間隔)を用い た場合について、フィルター分離 A R 法を用いてこの流域の水文流出過程の解析を行い、その結果として得 られた短時間単位の流出量における初期流量と地下水浸透能の関係、及び流出寄与率と眝留量の関係等を検 討し、水文流出系の流出過程を明らかにするすのである。

\section{2. 対象洪水}

流出モデルの定数解析に用いる洪水としては、中・大規模洪水が望ましいと考え、三保ダム地点で観測さ れた洪水のうち、ピーク流量が大きい上位15洪水を選定した(表一 1 )。

なお、三保ダム地点の流量データは、観測感度の鋭敏さやゲート操作の影響と見られる流量の微少変動 (以下、スパイクデータと称す) がある。本解析では、これらのスパイクデータを緩和するために、スパイ クの著しい流量 $200 \mathrm{~m}^{3} / \mathrm{s}$ 以下の流量に対して、以下のような平均化処理を行った。

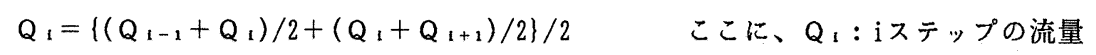

\section{A R 係数 (成分単位図) の同定}

\section{(1) 流量時系列の成分分㯆}

河川流量莪減部（ピーク後）の流量データQを時間 $\mathrm{t} に$ 対して対数プロットすると、両者の関係は一般に 勾配変化のはっきりした $2 、 3$ の直線部分から構成される。このときの直線の勾配、すなわち、流量莪減係

* 神奈川県企業庁管理局三保事務所

（†258-02 神奈川県足柄上郡山北町神尾田734）

**正会員 八千代エンジニヤリング株式会社

（テ153 東京都目黑区中目黑1-10-21） 
表 - 1 流出解析の対象洪水（ダム地点流量・ダム流域平均雨量）

\begin{tabular}{|c|c|c|c|c|c|c|}
\hline No. & 洪水名称 & $\begin{array}{c}\text { 初期流量 } \\
\left(\mathrm{m}^{3} / \mathrm{s}\right)\end{array}$ & $\begin{array}{c}ヒ^{\circ}-ク \text { 流量 } \\
\left(\mathrm{m}^{3} / \mathrm{s}\right)\end{array}$ & $\begin{array}{c}\text { 最大15分間雨量 } \\
(\mathrm{mm} / 15 \mathrm{~min})\end{array}$ & $\begin{array}{c}\text { 最大時間雨量 } \\
(\mathrm{mm} / \mathrm{hr})\end{array}$ & $\begin{array}{c}\text { 累加雨量 } \\
(\mathrm{mm})\end{array}$ \\
\hline 1 & $1979^{\circ} 10 / 17$ & 11 & 1322 & 20.5 & 66.2 & 359.1 \\
\hline 2 & $1981^{\circ} 8 / 21$ & 9 & 395 & 8.7 & 26.8 & 246.5 \\
\hline 3 & $1982^{\circ} 7 / 31$ & 10 & 1103 & 14.7 & 54.7 & 560.1 \\
\hline 4 & $1982^{\circ} 9 / 9$ & 10 & 607 & 10.2 & 32.0 & 413.0 \\
\hline 5 & $1983^{\circ} 8 / 14$ & 7 & 807 & 12.3 & 39.6 & 846.7 \\
\hline 6 & $1985^{\circ} 6 / 30$ & 30 & 715 & 9.0 & 32.1 & 302.0 \\
\hline 7 & $1986^{\circ} 9 / 2$ & 7 & 303 & 11.2 & 34.9 & 225.2 \\
\hline 8 & $1989^{\circ} 8 / 27$ & 8 & 416 & 12.9 & 40.7 & 254.4 \\
\hline 9 & $1989^{\circ} 9 / 19$ & 13 & 414 & 13.1 & 44.2 & 113.4 \\
\hline 10 & $1990^{\circ} 8 / 9$ & 6 & 714 & 13.5 & 42.4 & 386.4 \\
\hline 11 & $1990^{\circ} 9 / 19$ & 7 & 576 & 22.7 & 56.6 & 261.9 \\
\hline 12 & $1990^{\circ} 9 / 30$ & 14 & 429 & 9.3 & 31.9 & 189.8 \\
\hline 13 & $1991^{\prime} 8 / 20$ & 5 & 613 & 12.3 & 38.4 & 393.5 \\
\hline 14 & $1991^{\prime} 9 / 18$ & 30 & 508 & 12.0 & 40.7 & 303.0 \\
\hline 15 & $1992^{\prime} 9 / 25$ & 6 & 356 & 14.2 & 51.9 & 152.6 \\
\hline
\end{tabular}

数 (または時定数) は、地下水流出、中間流出、表面流出に対応する。三保ダム地点のピーク後流量を $\ln \left(Q_{0}\right.$ $/ \mathrm{Q}) \sim \mathrm{t}$ 平面にプロットすると、地下水流出成分に相当する時定数 $\mathrm{T}$ は各対象洪水で概ね等しく、 $\mathrm{T}_{\mathrm{c}}=35$ $\mathrm{hr}$ が得られた (図一 1 )。減衰係数 $\delta$ は滤波特性より $\delta=2.5$ として観測流量時系列の成分分離を行うと、重 み係数は $\alpha=0.071 \sim 0.105$ (平均0.090) となった。時間単位データの重み係数 $\alpha$ は $0.3 \sim 0.4$ 程度、日単位デ ータでは0.5〜0.6程度であるが、15分単位データでは時間単位データより、さらに小さくなることがわかる。

なお、重み係数 $\alpha$ は地下水成分流量時系列と観測流量時系列の減衰部が合致するように設定した。

また、本検討での成分分離は、地下水流出成分と中間・表面流出成分の 2 つに分離することとした。これ は、(a)対象洪水の $\ln \left(Q_{\mathrm{v}} / \mathrm{Q}\right) \sim \mathrm{t}$ 関係から1 2つの大洪水を除いて概ね 2 つ直線部分に近似される、(bモ デルをできるだけ単純にしたい、等の理由による。
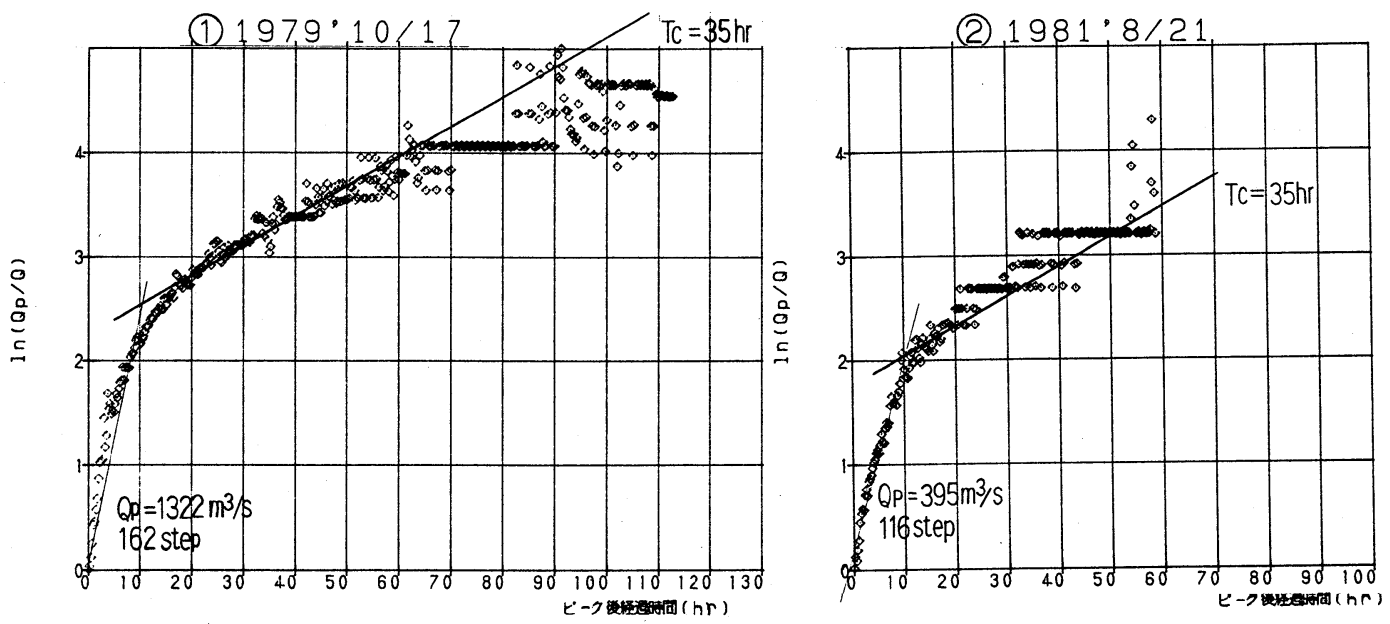

図-1 洪水派減部流量の自然対数プロット

\section{（2）A R 係数の決定}

分離後の成分流量時系列は線形系で表現され、各流出成分は式(1)により表される。

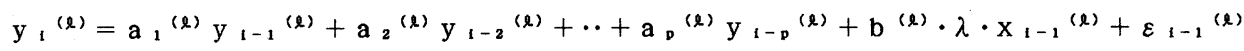

$$
\begin{aligned}
& \text { ここに、 } y_{1}: \text { i時の流出成分 } x_{1-1}: i-1 \text { 時の降雨量 (l) : 流出成分を示す添字 } \\
& \lambda \text { : 単位換算係数 } \mathrm{a}: \text { : R 係数 } \mathrm{b} \text { : 係数 }\left(\mathrm{b}=1-\mathrm{a}_{1}-\mathrm{a}_{2}-\cdots-\mathrm{a}_{\mathrm{p}}\right)
\end{aligned}
$$

洪水において降雨がゼロとなる莪減部、または降雨が白色雑音とみなせる期間に対して、式(1)を当てはめ、 連立一次方程式の解法を用いて、数学的に A R 係数を求めた。各洪水毎の A R 係数を比較するために、各成 
分の A R 係数を、系の応答特性が理解しやすい成分単位図に変換して15の対象洪水について示すと図一 2 の とおりである。図によれば、地下水流出成分、中間・表面流出成分とも、No.9およびNo.15の洪水を除いて、 成分単位図は概ね一致することがわかる。そこで、15の対象洪水の平均的な成分単位図を代表成分単位図 (代表 A R 係数)として設定した(表一 2 )。

表-2 代表成分単位図（代表 A R 係数）

\begin{tabular}{|c|c|c|c|c|c|}
\hline \multicolumn{3}{|c|}{ 地下水流出成分 } & \multicolumn{3}{|c|}{ 中間 - 表面流 出成 分 } \\
\hline 次 数 & A R 係数 & 単 位 & 次数 & A R 係数 & 単 位 図 \\
\hline 1 & 2.2499 & 継続時間：140.75hr (563ステッ $\left.7^{\circ}\right)$ & 1 & 1.2227 & 継続時間： $21.75 \mathrm{hr}\left(87 ス テ \% 7^{\circ}\right)$ \\
\hline 2 & -0.8433 & ピーク值 : $1.189 \mathrm{~m}^{3} / \mathrm{s}$ & 2 & 0.1268 & $7.998 \mathrm{~m}^{3} / \mathrm{s}$ \\
\hline 3 & -1.0668 & $16.75 \mathrm{hr}\left(67 ス テ ッ 7^{\circ}\right)$ & 3 & -0.3725 & 1.75hr( 7ステップ $)$ \\
\hline 4 & -0.6602 & - & - & - & - \\
\hline
\end{tabular}
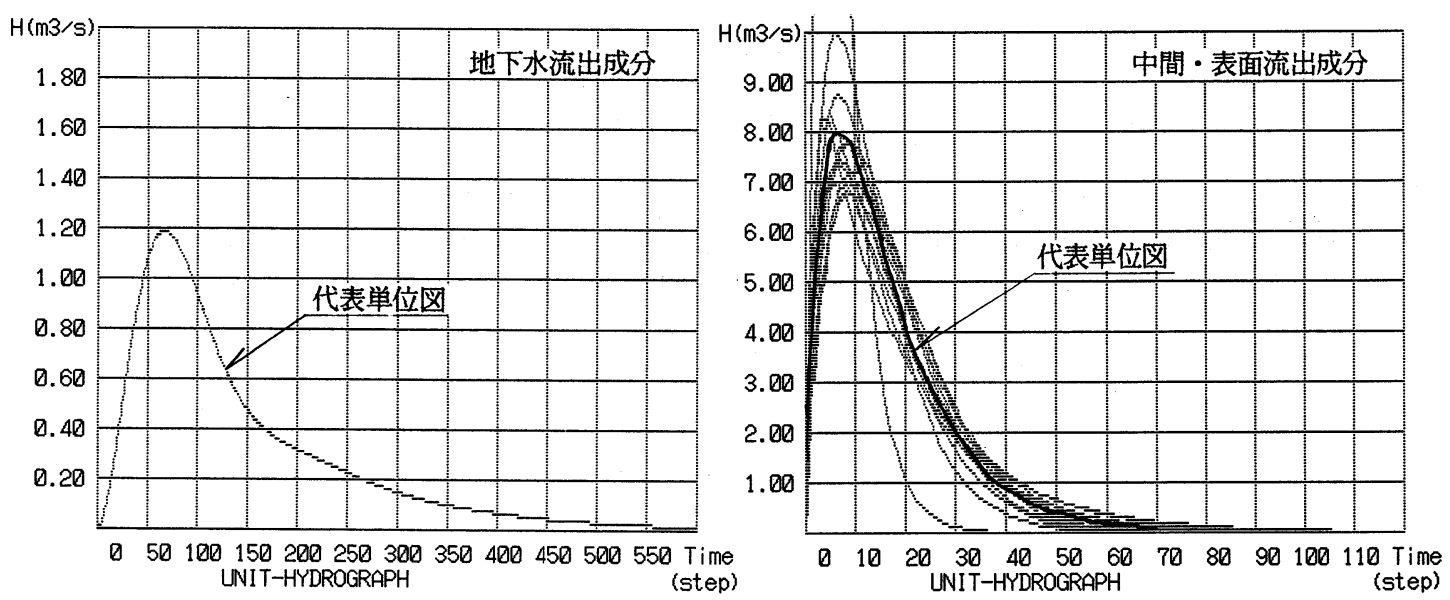

図-2 対象洪水の流出成分単位図

\section{4. 流出㝵程の検討}

\section{（1）有效降雨}

各洪水より得られた各成分の A R 係数と、数値フィルターによって分離した成分流量時系列により、式(1) を用いて成分降雨は逐一的に逆算される。しかし、本解析のような短時間単位 (15分)のデータの場合、僅か な流量のプラスマイナス(またはスパイク)データが観測されることが多く、逆算降雨にプラスマイナス成分 が頻出する結果となり、逐一法では良い結果は得られなかった。そこで、本解析では平滑化最小二乗法によ る降雨逆算を行った。また、各洪水毎の逆算成分降雨時系列は観湘降雨時系列と比較することにより、遅延 時間、伸長倍率を求めた (図一 3 )。

$\bigcirc$ 地下水流出成分 $\cdots$ 遅延時間 : $4 \mathrm{hr}(0 \sim 7 \mathrm{hr}$ 、平均 $4.00 \mathrm{hr})$ 伸長倍率: 3 倍 (2〜 倍、平均2.7倍)

中間・表面流出成分 $\cdots$ 遅延時間 : $0 \mathrm{hr}(0 \sim 1 \mathrm{hr}$ 、平均 $0.25 \mathrm{hr}$ 、 9 洪水が $0 \mathrm{hr})$

\section{（2）初期流量と地下水浸透能の関係}

地下水流出成分降雨の分離則は、『地下水流出成分降雨が最終地下水浸透能に達した後は地下水流出成分 降雨は降雨期間中で一定値を示す』とされている。しかし、地下水成分降雨の逆算結果によれぱ、最終地下 水浸透能に達した後にかなりの減少傾向を示す。また、最終地下水浸透能にいたる直前にこれを大きくオ一 バーシュートする傾向が著しく、最終地下水浸透能の2〜3倍に達する。

そこで、本解析では、オーバーシュートする地下浸透（地下水流出成分降雨）直後のゆるやかなカーブを 描く降雨成分のピーク值を、最終地下水浸透能として設定することとした。このようにして設定した最終地 下水浸透能およびオーバーシュート浸透能と、初期流量 qAの関係は図ー4に示すとおりである。 
これらによれば、最終地下水浸透能は初期流量の違いによる変化は小さく、概ね0.4〜 $1.0 \mathrm{~mm} / 15$ 分の間に あり、平均值は $0.62 \mathrm{~mm} / 15$ 分である。以上により、本解析で最終地下水浸透能は $0.6 \mathrm{~mm} / 15$ 分とし、フィルタ 一分離 A R 法による地下水流出成分降雨の分離則を用いて、地下水流出成分降雨の分離を行うこととした。

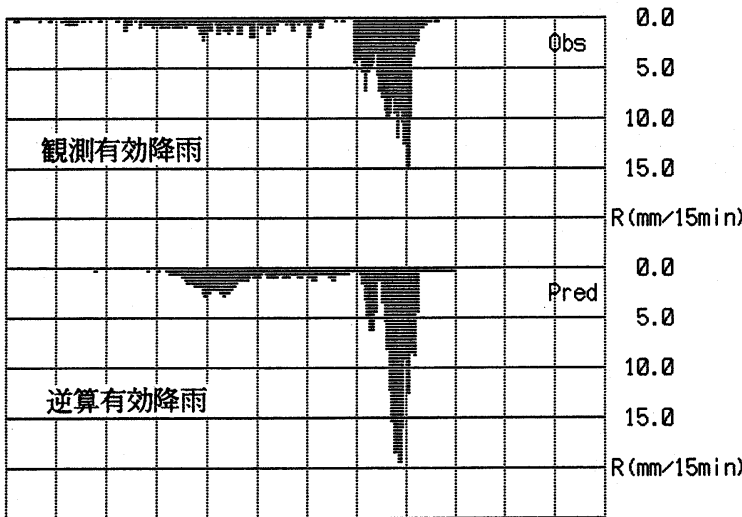

$0 \quad 20 \quad 40 \quad 60 \quad 80100120140160180200220$ Time (step) COMPARE RAINFALL (PRED \& OBS) (1979'10/17 Flood)

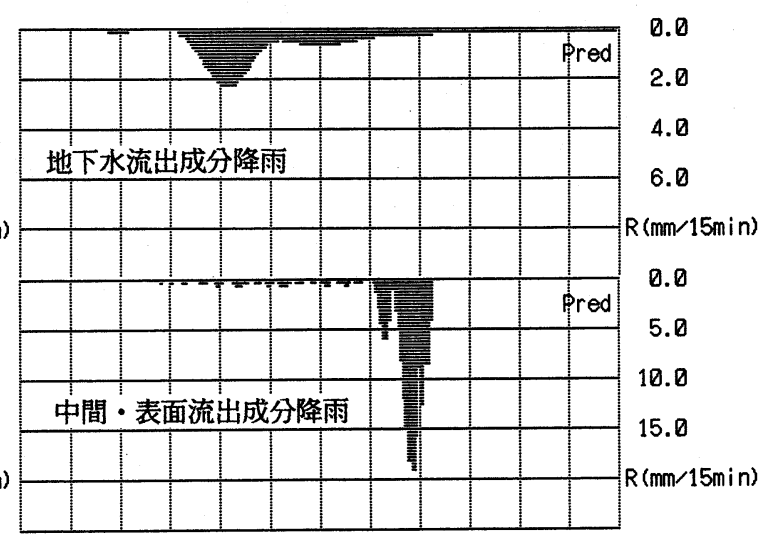

$0 \quad 20 \quad 40 \quad 60 \quad 80100120140160180200220$ Time(step) COMPARE RAINFALL (PRED \& OBS) (1979'10/17 Flood)

図-3 浸透過程による変形前の降雨時系列の推定結果

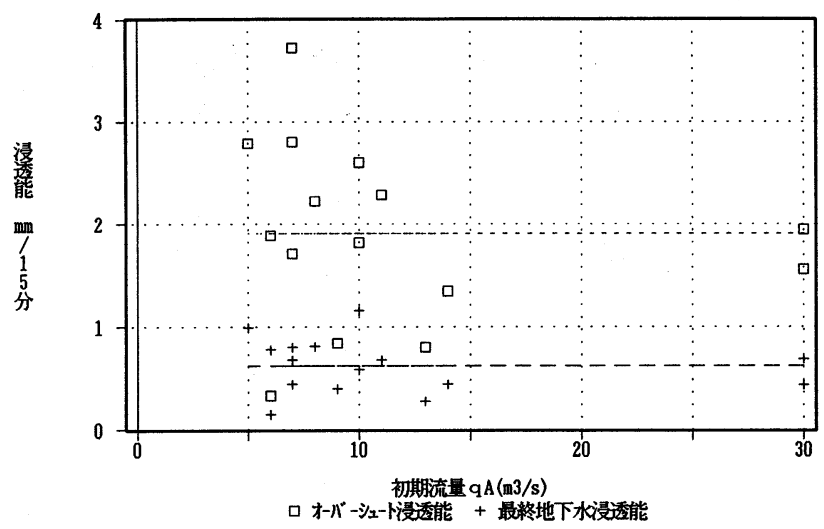

図一 4 初期流量 q A と最終地下水浸透能の関係

\section{（3）流出寄与域と眝留量との関係}

横軸に経過時間、縦軸に流出寄与面積率 $\mathrm{A}_{\mathrm{t}}(=\mathrm{a} / \mathrm{A})$ お よび流域眝留率 $\mathrm{S} / \mathrm{S}_{\mathrm{max}}$ をとり、15の対象洪水の 降雨期間中についてグラフ化した(図－5)。これらによれば、A，と $\mathrm{S} / \mathrm{S}_{\mathrm{max}}$ の変化傾向は全体的に見れば 概好一致しており、部分的流出寄与域（v.s.a.）に基づく中間・表面流出成分降雨の推定手法は本流域にお いてあ用いることができると考えられる。

次に、本手法を適用するために、洪水毎の $\mathrm{S}_{\mathrm{max}}$ の值および $\mathrm{A}$ こと $\mathrm{S} / \mathrm{S}_{\mathrm{max}}$ の関数関係を設定する。 流域最大眝留量 $\mathrm{S}_{\mathrm{max}}$ の推定

各洪水における $\mathrm{S}_{\mathrm{ma}} \mathrm{x}$ と累加雨量の関係は図ー6に示すように非常に良い相関関係が認められた。相関関 係式は、 $\mathrm{S}_{\mathrm{max}}=0.59 \times \mathrm{R}+35$ となる。

\section{$\mathrm{A}$ と $S / S_{\max }$ の関数関係の設定}

最大流出寄与面積率を『S $/ \mathrm{S}_{\mathrm{max}}$ がピークに至るまでの最大の $\mathrm{A}$ ，值』と定義して、最大流出寄与面積率 $\mathrm{A}_{\mathrm{Imax}}$ (1時間平均值)を求め、 $\mathrm{S}_{\mathrm{max}}$ との関係を示すと図ー 7 に示すとおりであり、両者は比較的良い相関を

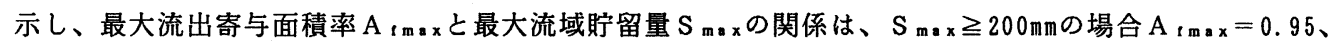

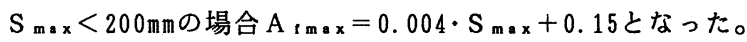


以上により、A，と $\mathrm{S} / \mathrm{S}_{\mathrm{max}}$ の関数関係は最大流出寄与面積率 $\mathrm{A}_{\mathrm{Im} \mathrm{m} \times \mathrm{x}}$ 用いて式(2)のように表現でき、 洪水毎に累加雨量から $\mathrm{S}_{\mathrm{m} \times \mathrm{x}}$ が得られれば、中間・表面流出成分降雨 $\mathrm{x}{ }^{(2)}$ は流出寄与面積率 $\mathrm{A}$ ，老用いて式 (3)により求められる。

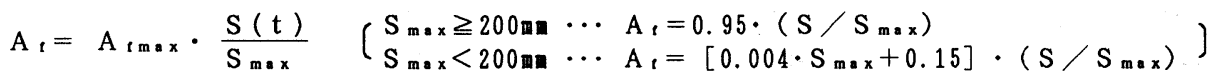

$$
\begin{aligned}
& \text { ここに、 } \mathrm{S}_{\max }=0.59 \cdot \mathrm{R}+35 \\
& \mathrm{X}^{(2)}(\mathrm{t})=\mathrm{A}_{\mathrm{t}} \cdot\left(\mathrm{X}(\mathrm{t})-\mathrm{X}^{(1)}(\mathrm{t})\right)
\end{aligned}
$$

また、洪水期間中の流出率の変化を、逆算有効降雨時系列と観測降雨時系列により調べると、洪水初期て は流出率は非常に小さく、降雨の継続とともに徐々に大きくなり、やがて一定值に近づくという過程をたど っている。したがって、流出率を一定として流量予測を行うのでは、予測精度の向上は望めず、v.s.a. に基 づく手法のように洪水期間中の流出率を変化させていく手法による予測が望ましいといえる。
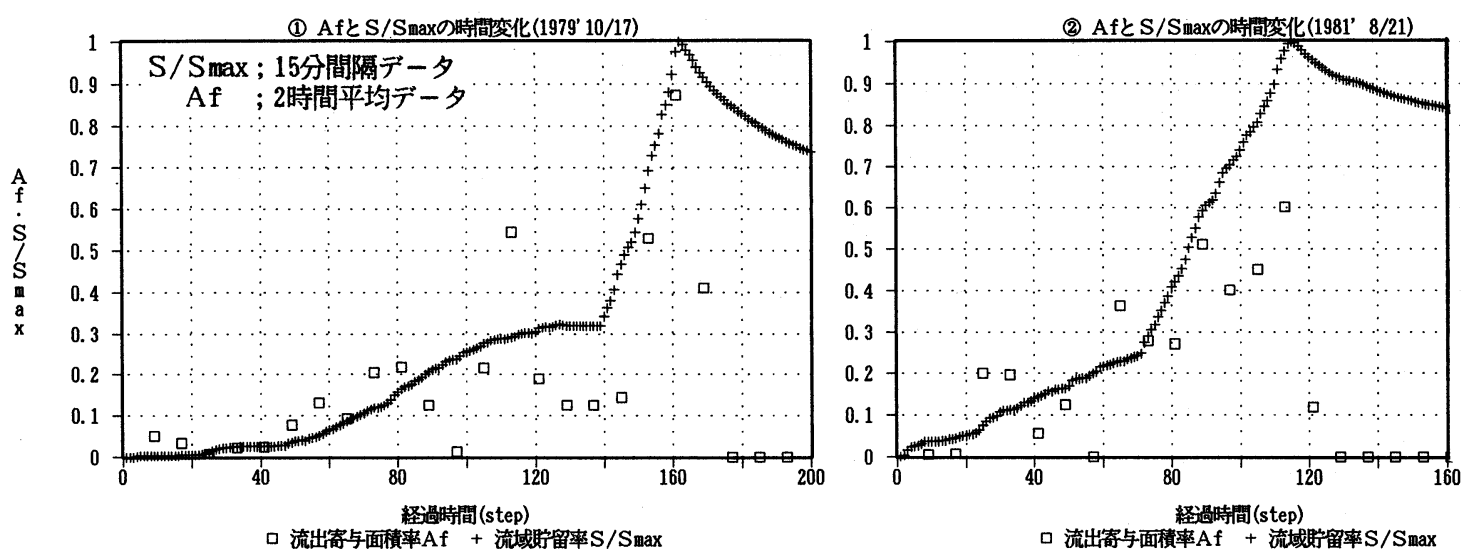

図-5 流出寄与面積率 A f c流域眝留率 $\mathrm{S} / \mathrm{S} \max$ の時間変化

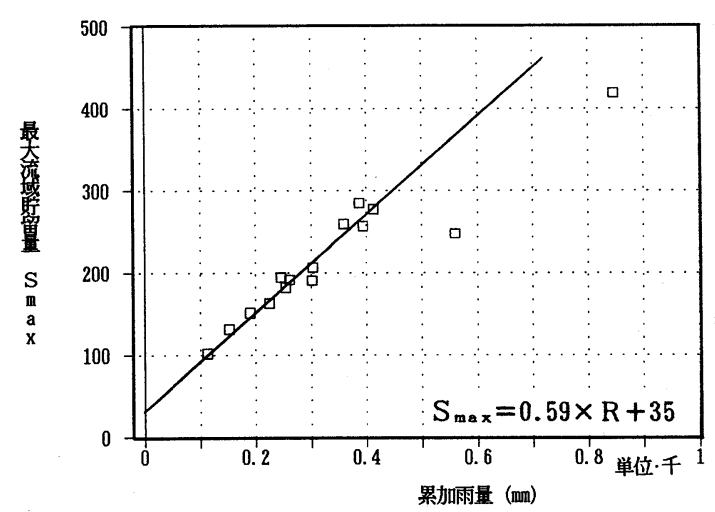

図-6 $\mathrm{S}_{\mathrm{max}}$ と累加雨量の関係

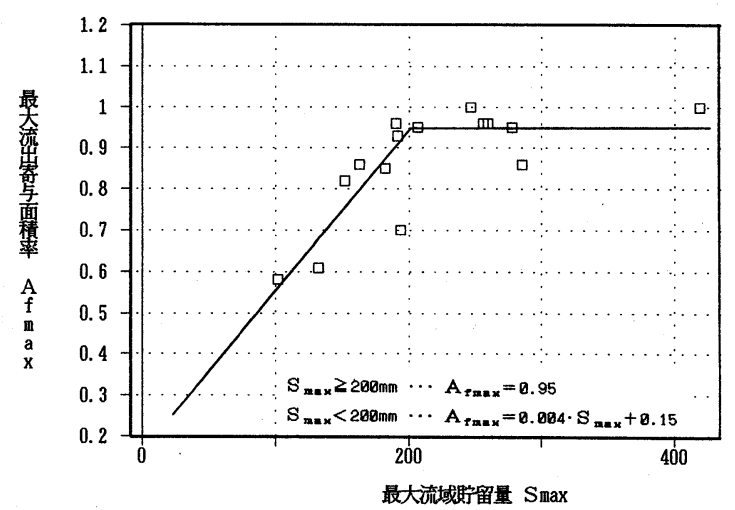

図- $7 \quad \mathrm{~S}_{\max }$ と $\mathrm{A}_{\mathrm{tmax}}$ (1時間平均值)との関係

\section{5. 流出モデルの道用性}

これまでの検討から得られた流出モデルを用いて、表ー 1 に示した15洪水(大洪水)および別途抽出した14 の中小洪水の流量再現計算を行い、流出モデルの妥当性を検証した。流量再現計算結果は図ー8に、ピーク 流量および総流出量の実測值と計算值の比較を図ー9に示した。

これらによれば、本検討で設定した流出モデルは、ピーク流量 $200 \mathrm{~m}^{3} / \mathrm{s}$ 以上および総流出量 $100 \mathrm{~mm}$ 以上(累 加雨量 $100 \mathrm{~mm}$ 以上)の適用範囲において、 $\pm 20 \sim 30 \%$ 以内の精度で洪水流量波形の再現が可能であり、流出モ デルとして十分な精度を有しているといえる。 

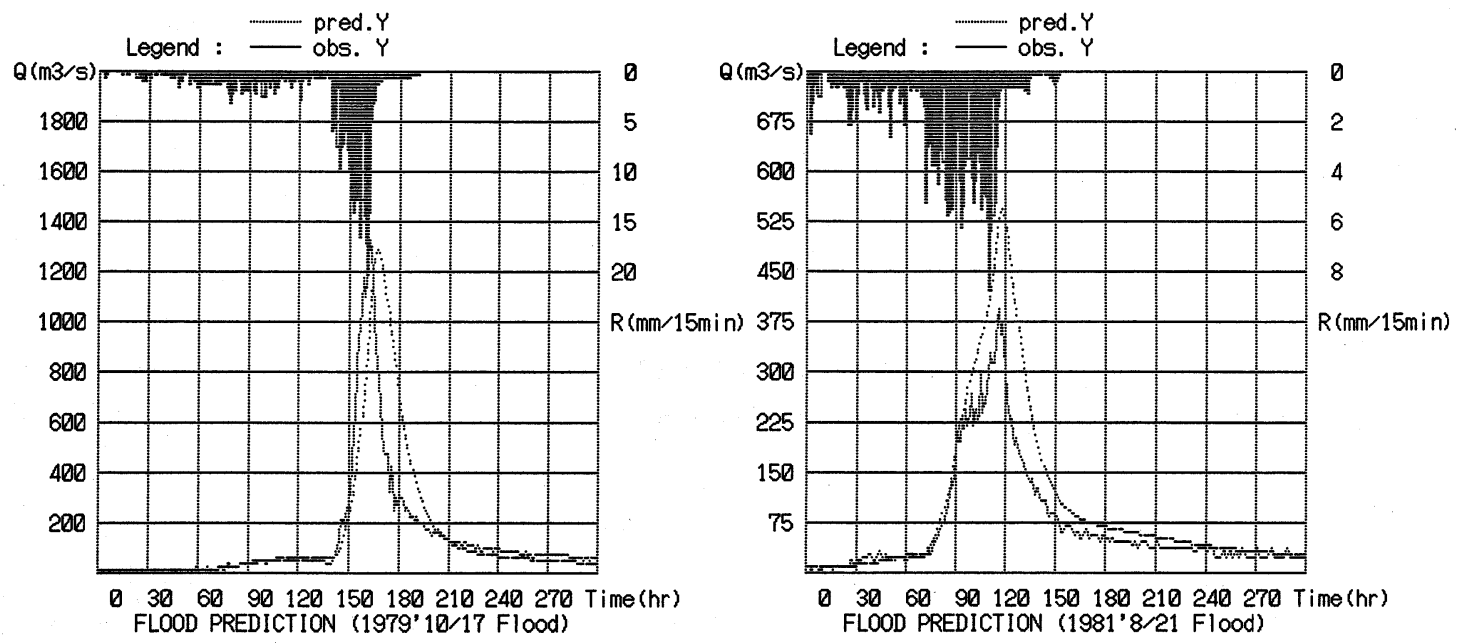

図-8 流出予测計算結果
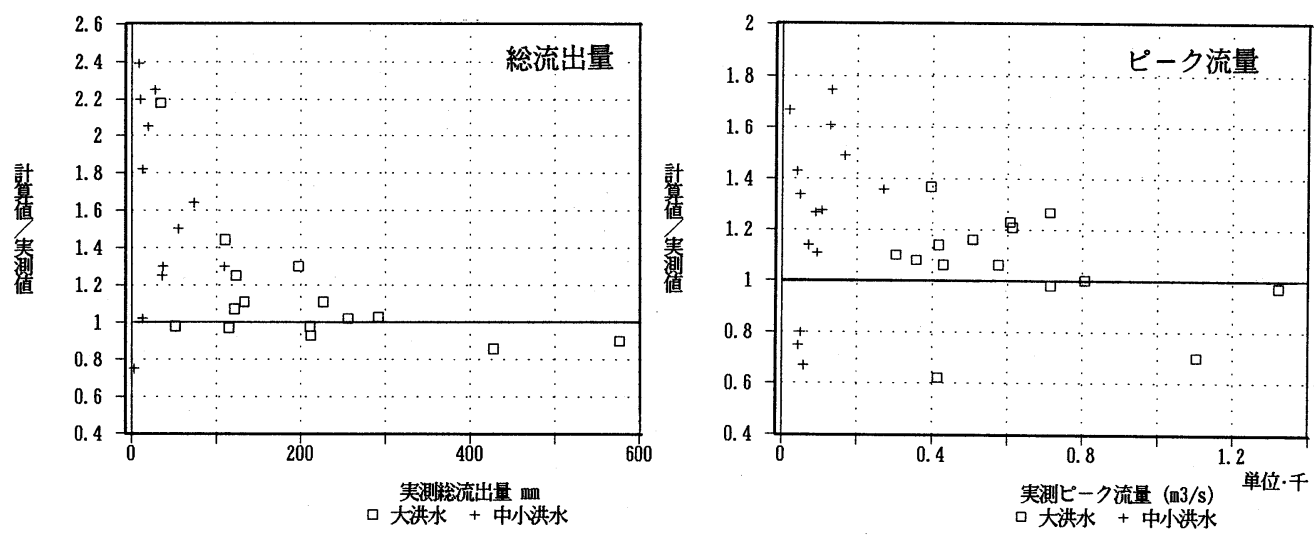

図-9 ピーク流量、総流出量の計算值と実測値の比較

\section{6.おわりに}

流出過程の非線形性がより強く現れると考えられる短時間単位水文データ(15分間隔)を用いて、フィル夕 一分離 A R 法による流出解析を行い、初期流量、貯留量及び流出寄与率等から短時間単位の水文流出系にお

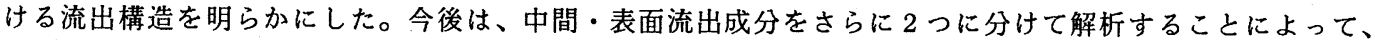
短時間降雨によるより明確な流出構造の把握、流出モデルの精度向上を行う予定である。

最後に、本研究を行うに当たって、暖かいご指導をいただきました宇都宮大学工学部建設学科の長谷部正 彦教授に感謝の意を表します。

$<<$ 参考文献 $>>$

（1）日野幹雄・長谷部正彦: 流量時系列のみによる流出解析について、土木学会論文報告集、第300号、1980年8月

（2）日野幹雄・長谷部正彦：フィルター分離A R 法による非線型流出系の同定と予測（時間単位）、土木学会論文報告 集、第324号、1982年8月

（3）日野幹雄・長谷部正彦: 流出率と湿潤指標としての洪水直前流量、土木学会論文報告集、第328号、1982年12月

（4）日野幹雄：パソコンによる中小河川洪水のオンライン予測の実際、第31回水理講演会論文集、1987年2月

（5）日野幹雄・長谷部正彦 : 水文流出解析（FORTRANとBASICによる）、森北出版株式会社、1985年7月 